\title{
ANALYSIS OF VILLAGE FUNDS AND QUALITY OF HUMAN RESOURCES ON THE POVERTY LEVELS AND COMMUNITY WELFARE IN THE REGENCY/CITY OF BALI PROVINCE, INDONESIA
}

\author{
Devi Ni Kadek Tasya Novita*, Yasa I Nyoman Mahaendra \\ Faculty of Economics and Business, University of Udayana, Bali, Indonesia \\ *E-mail: tasyanovita33@gmail.com
}

\begin{abstract}
Economic development in Indonesia is a process of building a complete human being, so that it can improve the community welfare. The main goal of economic development is poverty alleviation. The government through Nawacita is committed to developing Indonesia from the periphery, including by increasing development in villages. One of the government expenditures aimed at reducing poverty in rural areas is through financial assistance, namely the Village Fund. In addition to village funds, the quality of human resources also determines the poverty levels in each region. The quality of human resources includes the dimensions of one's education and health. The research objective was to analyze the effect of village funds and the quality of human resources on the poverty level and community welfare in the regencies/cities of Bali Province. The data used is panel data for regencies/cities in Bali Province in 2015 - 2019 obtained from the Central Statistics Agency for Bali Province, the Bali Province Community and Village Empowerment Service and the Directorate General of Fiscal Balance (DPJK)-Ministry of Finance of the Republic of Indonesia. The data analysis technique used in this study is descriptive statistics and path analysis. The results of the research analysis show that the village funds have no negative and insignificant effect on poverty levels. The quality of human resources has a negative and significant effect on the level of poverty. Village funds have no positive and insignificant effect on community welfare. The quality of human resources has a positive and significant impact on community welfare. The poverty levels have a negative and significant effect on community welfare. The Village funds indirectly have no significantly effect on community welfare through poverty levels. The quality of human resources indirectly has a significantly on community welfare through the poverty levels in the regencies/cities in the Province of Bali.
\end{abstract}

\section{KEY WORDS}

Village funds, quality of human resources, poverty level, community welfare.

Community welfare is one of the goals of sustainable development goals (SDGs) and is a reflection of the success of development carried out by the government, measured by using the human development index (IPM) (Wriana, 2020). Community welfare is the goal of the government, both central and local, through the development process (Putra, 2015). Development has a broad meaning, namely a multi-dimensional process that includes important changes in the acceleration of economic growth, social structure, inequality, unemployment and poverty alleviation (Todaro, 2000). The implementation of development must be able to realize an equitable distribution of income for the entire community (Bayu Nugraha, 2013). The main objective of economic development efforts in addition to creating the highest growth, must also be able to alleviate or reduce the level of poverty, income inequality, and the unemployment rate (Todaro, 2003). Poverty is a global phenomenon and a complex problem that is very concerning, and can occur in any part of the world. Bali Province is no exception, even in Indonesia this phenomenon can occur. Poverty is not only related to the problem of low levels of income and consumption, but also to the low level of education, health and powerlessness to participate in development as well as various problems related to human development (Diana, 2005). Bali is a province that has biodiversity as well as artistic and cultural heritage, thus creating opportunities in the tourism sector (Tajddini et al, 2017). So far, Bali has relied heavily on the rapidly growing tourism 
sector. Not a few people think that the Balinese are far from poverty. During 2015-2019 the development of poverty rates in districts/cities in Bali Province varied in each region, as presented in Table 1.

Table 1 - Development of Poverty Levels by Regencies/Cities in Bali Province in 2015-2019 (\%)

\begin{tabular}{|c|c|c|c|c|c|}
\hline Regencies/Cities & 2015 & 2016 & 2017 & 2018 & 2019 \\
\hline Jembrana & 5,84 & 5,33 & 5,38 & 5,20 & 4,88 \\
\hline Tabanan & 5,52 & 5,00 & 4,92 & 4,46 & 4,21 \\
\hline Badung & 2,33 & 2,06 & 2,06 & 1,98 & 1,78 \\
\hline Gianyar & 4,61 & 4,44 & 4,46 & 4,19 & 3,88 \\
\hline Klungkung & 6,91 & 6,35 & 6,29 & 5,86 & 5,40 \\
\hline Bangli & 5,73 & 5,22 & 5,23 & 4,89 & 4,44 \\
\hline Karangasem & 7,44 & 6,61 & 6,55 & 6,28 & 6,25 \\
\hline Buleleng & 6,74 & 5,79 & 5,74 & 5,36 & 5,19 \\
\hline Denpasar City & 2,39 & 2,15 & 2,27 & 2,24 & 2,10 \\
\hline Bali Province & 4,74 & 4,25 & 4,25 & 4,01 & 3,79 \\
\hline
\end{tabular}

Source: Central Bureau of Statistics of Bali Province, 2020.

In 2019, the highest percentage of poverty rate was in Karangasem Regency at 6.25 percent, followed by Klungkung Regency at 5.40 percent. Buleleng Regency occupies the third position with the highest poverty rate reaching 5.19 percent. This is different from Badung Regency and Denpasar City, where the poverty rate in both regions is lower than the poverty level of Bali Province. In 2019 the poverty rate of Badung Regency reached 1.78 percent, followed by Denpasar City with the second lowest poverty rate of 2.10 percent. Of the nine regencies and cities in Bali Province, there are two regencies/cities with poverty levels below the Province of Bali, while the other seven regencies have poverty levels above the provincial poverty level, so that there is a disparity in the level of poverty between regions in the Province of Bali.

Various efforts have been made by the government to be able to suppress and even eradicate poverty, through policies that are outlined in the formulation of poverty alleviation programs. There is a need for synergy between the central and regional governments in increasing the level of prosperity and welfare of the people in their regions. The government's role in this matter is very large through the financing made by the government (Dalamagas et al, 2010). The Indonesian government through Nawacita is committed to developing Indonesia from the periphery, including by increasing development in villages. In 2015, the government provided assistance through financing, namely the Village Fund sourced from the State Revenue and Expenditure Budget (APBN) and transferred through the district/city Regional Revenue and Expenditure Budget (APBD). Village funds are one of the government's efforts to alleviate poverty in villages in Indonesia (Chuzaimah, 2020). The key to success for the welfare of the community in developing the village is the strong touch of initiation, innovation, creation and cooperation between village officials and the community in realizing a common goal. Another important factor as a stimulus that is able to change and facilitate the wheels of periphery economic development in the village is the existence and utilization of village funds. The village program will run according to the target time and as expected if it is supported by village funds which will facilitate the development process in the village. The objectives of the distribution of Village Funds include: 1) To improve public services in the village, 2) To alleviate poverty, 3) To advance the village economy, 4) To overcome the development gap between villages, and 5). To strengthen the village community as the subject of development. The benefits of the village fund are prioritized to finance development and community empowerment in order to improve the welfare of rural communities, the quality of human life, and poverty alleviation.

With a well-targeted and equitable allocation of funds, it is hoped that the regional development process can be improved. However, in reality, the provision of financial assistance to villages has not been fully able to improve equitable welfare, especially for the people in the regency/city area of Bali Province. This is indicated by the fact that there are still several regencies/cities in Bali Province with Human Development Index (IPM) 
achievements below the average Human Development Index (HDI) in Bali Province, as shown in Table 2.

Table 2 - Development of Human Development Index by District /City in Bali Province 2015-2019 (in points)

\begin{tabular}{|c|c|c|c|c|c|}
\hline Regencies/Cities & 2015 & 2016 & 2017 & 2018 & 2019 \\
\hline Jembrana & 69,66 & 70,38 & 70,72 & 71,65 & 72,35 \\
\hline Tabanan & 73,54 & 74,19 & 74,86 & 75,45 & 76,16 \\
\hline Badung & 78,86 & 79,80 & 80,54 & 80,87 & 81,59 \\
\hline Gianyar & 75,03 & 75,70 & 76,09 & 76,61 & 77,14 \\
\hline Klungkung & 68,98 & 69,31 & 70,13 & 70,90 & 71,71 \\
\hline Bangli & 66,24 & 67,03 & 68,24 & 68,96 & 69,35 \\
\hline Karangasem & 64,68 & 65,23 & 65,57 & 66,49 & 67,34 \\
\hline Buleleng & 70,03 & 70,65 & 71,11 & 71,70 & 72,30 \\
\hline Denpasar City & 82,24 & 82,58 & 83,01 & 83,30 & 83,68 \\
\hline Bali Province & 73,27 & 73,65 & 74,30 & 74,77 & 75,38 \\
\hline
\end{tabular}

Source: Central Bureau of Statistics of Bali Province, 2020.

The United Nations Development Program (UNDP) introduced the concept of the quality of human capital, namely the Human Development Index Human Development Index or (IPM). HDI contains three important aspects of the process of human development that is associated with the fulfillment aspect will live a long life (Longevity) and healthy living (healthy life), to acquire knowledge (the knowledge) and have access to resources that can meet the standards of living. These three aspects are important aspects in human development and are very influential on poverty (Yani Mulyaningsih, 2008).

Table 2 explains that the Development of the Human Development Index by regencies/cities in Bali Province continues to increase every year. In 2015, the lowest HDI in Bali was 73.27 points. It continues to increase every year to reach 75.38 points in 2019 . Of the nine regencies/cities in Bali Province, there are four regencies/cities in Bali with the Human Development Index achievement above the Human Development Index achievement in Bali Province. Denpasar City was ranked first with the highest achievement of the Human Development Index, which was 83.68 points. There are five districts with the Human Development Index achievement below the Human Development Index achievement of the Province of Bali. One of them is Karangasem Regency with the lowest achievement of the Human Development Index, which is 67.34 points. According to the Central Statistics Agency (BPS) of Bali Province, the Human Development Index (IPM) explains how the population can access development outcomes in obtaining decent income, health and education, so as to encourage people to be more productive.

In addition to village funds, the quality of human resources $(\mathrm{HR})$ greatly determines the level of poverty and community welfare in each region. According to Leker \& Ponthiere (2015), the quality of human resources is important in expanding job opportunities which include education and health levels. Related to poverty, education provides the ability to develop through mastery of knowledge and skills that will increase productivity. Such linkages are often used to design development programs for a region or country in overcoming the problem of poverty. To produce quality human resources, education is an important thing and for that improving the quality of human resources absolutely must be done. With quality human resources, it can provide a multiplier effect on the development of a region, especially economic development, the success of economic development that will affect the welfare of the community in an area.

\section{METHODS OF RESEARCH}

This study uses quantitative and qualitative data obtained from the Central Statistics Agency of Bali Province, the Bali Province Community and Village Empowerment Service and the Directorate General of Fiscal Balance (DPJK)-Ministry of Finance of the Republic of Indonesia. The observation points in this study are in districts/cities in Bali Province using 
panel data from districts/cities in Bali Province in 2015 - 2019 with a total of 45 data observation points.

The operational definitions of the research variables are 1) Village Funds are measured by the development of village funds according to districts/cities in Bali Province during 20152019 in rupiah. 2) The quality of human resources is measured by using the expectation of years of schooling in districts/cities in Bali Province during 2015 - 2019 with units of year. 3). The poverty rate is measured by using the percentage of poor people in districts/cities in Bali Province during 2015 - 2019 in percent units. 4). Community welfare is measured by using an implicit indicator, namely the human development index (HDI) in the districts/cities of Bali Province during 2015-2019 with units of points.

The analytical technique used in this research is descriptive analysis and path analysis as well as structural equations to analyze the influence of village funds and the quality of human resources (HR) on poverty levels and community welfare in districts/cities of Bali Province using SPSS software. The complete relationship between research variables is presented in the following path diagram.

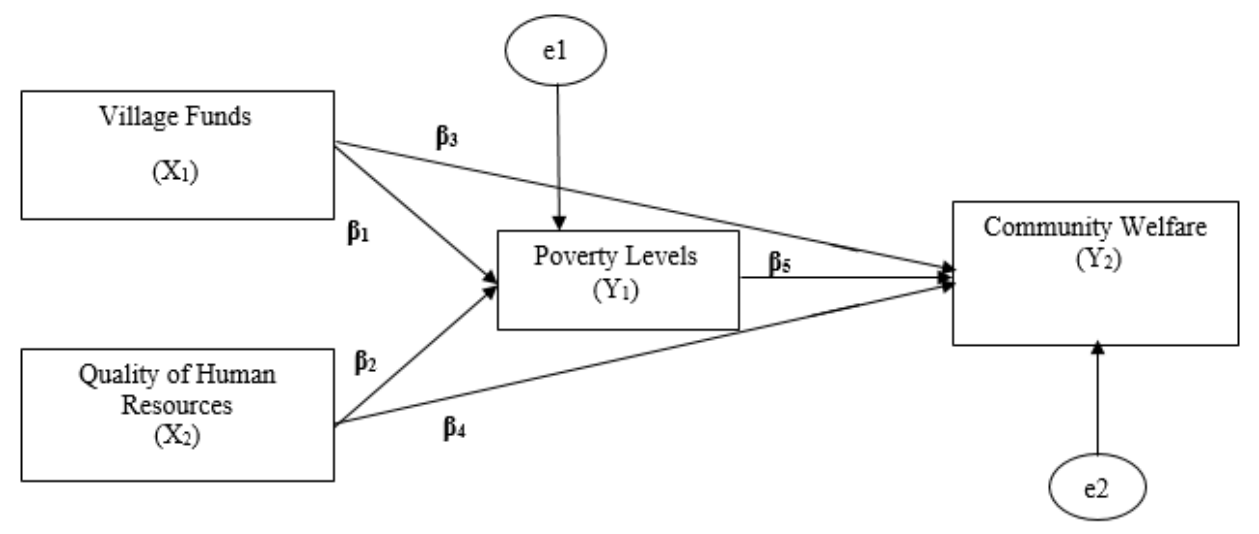

Figure 1 - Path Diagram of Relationship between Variables Influence of Village Funds and Quality of Human Resources on Poverty Levels and Welfare of Regency/City Community in Bali Province

The regression equation used in this study is as follows:

$$
\begin{aligned}
& Y_{1}={ }_{1} X_{1+2} X_{2}+{ }_{+} e_{1} \\
& Y_{2}={ }_{3} X_{1+4} X_{2}+5 Y_{1}++e_{2}
\end{aligned}
$$

Where: $Y_{1}=$ Poverty Level; $Y_{2}=$ Community Welfare; $\beta_{1,2,3,4,5 \text { Welfare, }}=$ regression coefficient or slope; $\mathrm{X}_{1}=$ Village Fund; $\mathrm{X}_{2}=$ Quality of Human Resources; $\mathrm{e}=$ Standard error value.

\section{RESULTS AND DISCUSSION}

Descriptive statistical analysis provides an overview or description of data as seen from the minimum, maximum, values mean, and standard deviation with $\mathrm{N}$ being the number of observation points. The results of descriptive statistical analysis can be seen in Table 3.

Table 3 - Statistical Results Description of Variables of Village Funds and Quality of Human Resources, Against Poverty Levels and Community Welfare in Regencies/Cities in Bali Province,

\begin{tabular}{|c|c|c|c|c|c|}
\hline \multicolumn{6}{|l|}{ Descriptive Statistics } \\
\hline & $\mathrm{N}$ & Minimum & Maximum & Mean & Std. Deviation \\
\hline Village Funds & 45 & 9.72 & 124.02 & 5.11 & 29.52 \\
\hline Quality of Human Resources & 45 & 11.36 & 13.99 & 12.92 & 0.67 \\
\hline Poverty Levels & 45 & 1.78 & 7.44 & 4.71 & 1.58 \\
\hline Community Welfare & 45 & 64.68 & 83.68 & 73.37 & 5.47 \\
\hline Valid N (list wise) & 45 & & & & \\
\hline
\end{tabular}
2010-2019

Source: Data processed, 2020. 
The descriptive statistics in Table 3 show that the minimum and maximum values of the village fund variable (X1) are 9.72 and 124.02. The average (mean) is 5.11 with a standard deviation of 29.52, this means that there is a difference in the value of the village funds studied against the average value of 29.52. The minimum and maximum values of the variable quality of human resources (X2) are 11.36 and 13.99. The average (mean) is 12.92 with a standard deviation of 0.67 , this means that there is a difference in the value of the quality of human resources studied against the average value of 0.67 . The minimum and maximum value of the poverty level $(\mathrm{Y} 1)$ is 1.78 and 7.44 . Average (mean) of 4.71 with a standard deviation of 1.58 , this means that there is a difference in the poverty value studied against the average value of 1.58 . The minimum and maximum value of community welfare (Y2) is 64.68 and 83.68. The average (mean) is 73.37 with a standard deviation of 5.47 , this means that there is a difference in the value of the welfare of the people studied against the average value of 5.47 .

Direct effect analysis can explain the relationship between research variables using the SPSS program. To find out the direct influence between variables, it can be seen from the results of the analysis of the path coefficient values shown in Table 4.

Table 4 - Coefficient Value of Direct Effects between Village Fund Variables and the Quality of Human

Resources on Poverty Levels and Community Welfare, in Regencies/Cities in Bali Province, 2015-2019

\begin{tabular}{llllll}
\hline Regression & Coefficient & Std Error & T-statistic & Sig. & Information \\
\hline $\mathrm{X}_{1} \longrightarrow \mathrm{Y}_{1}$ & 0.055 & 0.129 & 7.737 & 0.547 & No negative and insignificant effect \\
$\mathrm{X}_{2} \longrightarrow \mathrm{Y}_{1}$ & -0.808 & 0.211 & -8.965 & 0.000 & Negative and significant \\
$\mathrm{X}_{1} \longrightarrow \mathrm{Y}_{2}$ & -0.062 & 0.190 & -1.597 & 0.118 & No positive and insignificant effect \\
$\mathrm{X}_{2} \longrightarrow \mathrm{Y}_{2}$ & 0.476 & 0.530 & 7.257 & 0.000 & Positive and significant \\
$\mathrm{Y}_{1} \longrightarrow \mathrm{Y}_{2}$ & -0.537 & 0.227 & -8.171 & 0.000 & Negative and significant \\
\hline
\end{tabular}

Source: Processed Data, 2020.

Information: $X_{1}$ : Village Fund; $X_{2}$ : Community Welfare; $Y_{1}$ : Poverty Level; $Y_{2}$ : Community Welfare.

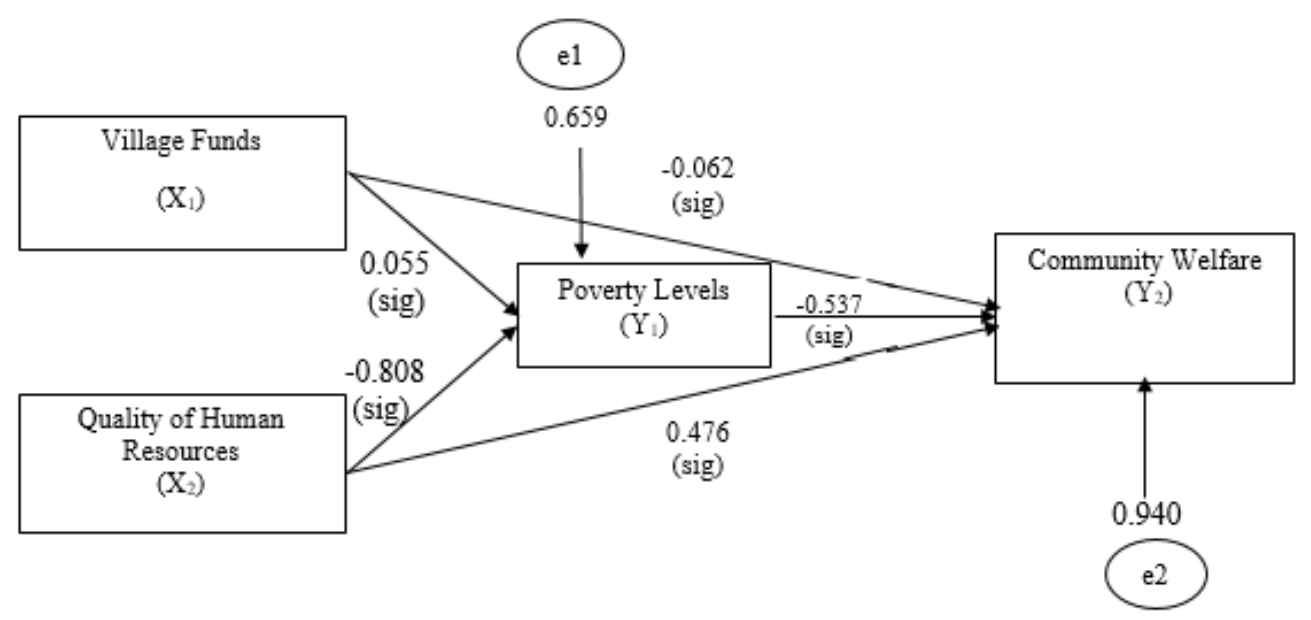

Figure 2 - Path Coefficient of Effect of Village Funds and Quality of Human Resources on Poverty Levels and District/City Community Welfare in Bali Province

Based on Table 4, it can be explained that village fund variable (X1) does not have a negative and significant effect on the poverty level $(\mathrm{Y} 1)$ with a significance value of 0.547 or greater than 5 percent, meaning that the higher the village funds obtained, it has not been able to reduce the poverty level in the districts/cities of Bali Province. The variable quality of human resources $(\mathrm{X} 2)$ has a negative and significant effect on the poverty level (Y1) with a significance value of 0.000 or less than 5 percent, meaning that the higher the quality of human resources, in this case human capital, the poverty rate in the district/city of the province. Bali is going down. The village fund variable $(\mathrm{X} 1)$ has no positive and significant effect on people's welfare (Y2) with a significance value of 0.118 or greater than 5 percent, 
meaning that the higher the allocated village funds, it does not necessarily improve the welfare of the people in the districts/cities of Bali Province. The variable quality of human resources (X2) has a positive and significant effect on people's welfare (Y2) with a significance value of 0.000 or less than 5 percent, meaning that the higher the quality of human resources, the more able to improve their welfare. The poverty level variable (Y1) has a negative and significant effect on people's welfare (Y2) with a significance value of 0.000 or less than 5 percent, meaning that the higher the poverty level, the people's welfare will decrease. The complete relationship between research variables is also presented in the path diagram in Figure 2. If it is observed that there is no path coefficient that has a value of more than one.

There are several relationships which are indirect effects between research variables. To determine the indirect effect between variables, it can be seen from the results of the analysis of the value of the indirect effect which was tested using the Sobel test presented in Table 5.

Table 5 - Indirect Coefficient Values of the Village Fund Variables and Quality of Human Resources on Poverty Levels and Community Welfare, in Regencies/Cities in Bali Province 2015-2019

\begin{tabular}{lllll}
\hline Variable Relationship & Variable Mediation & Sab & $Z$ & Information \\
\hline $\mathrm{X}_{1} \longrightarrow \mathrm{Y}_{2}$ & $\mathrm{Y}_{1}$ & 58,54 & -2.46 & Not Significant \\
$\mathrm{X}_{2} \longrightarrow \mathrm{Y}_{2}$ & $\mathrm{Y}_{1}$ & 577,727 & 6.07 & Significant \\
\hline
\end{tabular}

Source: Data processed, 2020.

Information: X1: Village Fund; X2: Quality of Human Resources; Y1: Poverty Level; Y2: Community Welfare.

Based on Table 5, it is shown that the indirect effect of village funds (X1) on the level of community welfare (Y2) through the poverty level $(\mathrm{Y} 1)$ has a calculated $\mathrm{Z}$ value of $-2.46<$ -1.96 , then $\mathrm{HO}$ is rejected and $\mathrm{H} 1$ is accepted. This means that village funds do not indirectly affect the welfare of the community. The indirect effect of the quality of human resources (X2) on the welfare of the community through the poverty level has a z-count value of 6.07 1.96, then $\mathrm{HO}$ is rejected and $\mathrm{H} 1$ is accepted. This means that the quality of human resources indirectly affects the welfare of the community through the level of poverty.

\section{DISCUSSION OF RESULTS}

The Effect of Village Funds on Poverty Levels in Regency/City of Bali Province. The results of the analysis show that village funds have no negative and insignificant effect on the poverty level in the regencies/cities of Bali Province, meaning that the higher the village funds allocated by the central government, it has not been able to reduce the poverty level in the regencies/cities of Bali Province. The results of this study are in line with research conducted by Sihite (2020) which states that village funds have no significant effect on poverty levels.

The Effect of the Quality of Human Resources on the Poverty Level in the Regency/City of Bali Province. The results of the analysis show that The quality of human resources has a negative and significant effect on the level of poverty in the regencies/cities of Bali Province. This means that the higher the quality possessed by human resources, in this case human capital, the lower the poverty rate in the regencies/cities of Bali Province. The results of this study are in line with research conducted by Abu Kosim (2010) which states that the quality of human resources has a negative effect on poverty levels.

The Effect of Village Funds on Community Welfare in Regency/City of Bali Province. The results of the analysis show that village funds have no positive and insignificant effect on the welfare of the people in the regencies/cities of Bali Province. This means that the high allocation of village funds does not necessarily improve the welfare of the people in the regencies/cities of Bali Province. The results of this study are supported by research by Wardani and Utami (2020) which states that the management of village funds does not affect the welfare of the community. Kurniawati's research (2017) states that village funds have no effect on community welfare. 
The Eeffect of Quality of Human Resources on Community Welfare in Regency/City of Bali Province. The test results show that the quality of human resources has a positive and significant effect on people's welfare. This means that the higher the quality of human resources, the person will be able to improve their welfare. According to Harbison $\mathrm{FH}$ (Todaro, 1995), Human Resources are the main foundation for the welfare of each region. The quality of human resources is often indicated by the level of education and health. The higher the level of education and health of a person, it is expected that the higher the productivity and the higher the income and the greater the opportunity to be classified as not poor (Abu Kosim, 2010).

The Direct Effect of Poverty Levels on Community Welfare in the Regency/City of Bali Province. The test results show that the poverty level has a negative and significant effect on people's welfare. This means that the higher the level of poverty, the welfare of the community will decrease. The results of this study are supported by the research of Chaniago (2016) which states that the level of poverty has a negative and significant effect on Community Welfare in the Regency/City of Bengkulu Province. Community welfare is a reflection of the success of human development carried out by the government. The results of the Pratama research (2019) which states that poverty is closely related to human development. The relationship between the level of poverty and human development, namely the number of poor people also affects human development. Residents belonging to this group generally have limitations on factors of production, so that access to economic activities is hampered. As a result, productivity becomes low, in turn the income received is far from sufficient and even the income received is less. This will have an impact on meeting basic needs, such as the need for food, clothing and housing. Moreover, for other needs such as education, health and others become hampered.

Indirect Effect of Village Funds on Community Welfare through Poverty Levels in Regency/City of Bali Province. The results of data analysis show that village funds do not have an indirect and insignificant effect on people's welfare through the poverty level in regencies/cities of Bali Province.

Indirect Effect of Quality of Human Resources on Community Welfare through Poverty Levels in Regency/City of Bali Province. The results of the analysis show that the quality of human resources indirectly affects the welfare of the community through poverty levels. This means that the higher the quality of human resources, the welfare will increase so that the poverty level will decrease. Quality human resources can provide a multiplier effect on the development of a country, especially economic development. The success of economic development that will affect the welfare of the community in an area and away from poverty (Notoatmodjo, 2009).

\section{CONCLUSION}

Based on the analysis and discussion of the data, it can be concluded several things as follows

- Village funds have no negative and insignificant effect on the poverty level in the regencies/cities of Bali Province. Meanwhile, the quality of human resources has a positive and significant impact on the welfare of the people in the regencies/cities of Bali Province;

- Village funds have a non-positive and insignificant effect on the welfare of the people in the regencies/cities of Bali Province. The variable quality of human resources has a positive and significant influence on the welfare of the people in the regencies/cities of Bali Province. Meanwhile, the poverty rate has a negative and significant influence on the welfare of the people in the regency/city of Bali Province;

- Village funds do not indirectly affect the welfare of the community through the level of poverty, while the quality of human resources indirectly affects the welfare of the community through the level of poverty in the regencies/cities of Bali Province. 


\section{SUGGESTIONS}

Based on the results of the analysis and conclusions above, it is necessary to provide training and empowerment to the management of village officials in terms of managing village funds so that they are able to adjust the allocation of village funds according to village needs and the impact can be felt by the village community. In addition, the Government is expected to be able to maintain its active role in improving the quality of human resources in this case education through policy instruments, namely fiscal policy, by increasing the allocation of funds for the education function (education budget) in accordance with the 1945 Constitution, which is at least 20 percent, so that it can support efforts to improve and improvement of the quality of human resources, in this case human capital, to be more productive and to increase the human development index, so as to reduce poverty and encourage the achievement of national goals for the welfare of society.

\section{REFERENCES}

1. Abu Kosim, M. Syirod Saleh and Taufiq. 2010. Analisis Kualitas Sumber Daya Manusia and Tingkat Kemiskinan Di Kabupaten Ogan Komering Ilir. Jurnal Ekonomi Pembangunan, Volume 8, No.1 hal: 1 - 11 ISSN 1829-5843

2. Bayu Nugraha Putra, I Putu Gede and I Nengah Kartika. 2013. Analisis Sektor-Sektor Potensial Dalam Menentukan Prioritas Pembangunan Di Kabupaten Badung Tahun 2001-2011. E-Jurnal Ekonomi Pembangunan, Vol, 2 No.9:401-405 ISSN: 2303-0178

3. BPS Provinsi Bali. 2020. Indeks Pembangunan Manusia Kabupaten/kota di Provinsi Bali 2015-2019. Denpasar: BPS Bali

4. BPS Provinsi Bali. 2020. Harapan Lama Sekolah menurut Kabupaten/kota di Provinsi Bali 2015-2019. Denpasar: BPS Bali

5. BPS Provinsi Bali. 2020. Presentase Tingkat Kemiskinan menurut Kabupaten/kota di Provinsi Bali 2015-2019. Denpasar: BPS Bali

6. Chaniago, Parlan and Rusdi, Muhamad.2016. Analisis Pengaruh Pertumbuhan Ekonomi, Tingkat Kemiskinan Terhadap Kesejahteraan Masyarakat Di Kabupaten and Kotaprovinsi Bengkulu. Undergraduated Thesis, Universitas Bengkulu.

7. Chuzaimah Batubara, Isnaini Harahap \& Marpuah. 2020. The Impact Of Village Funds On Enhanching Welfare Of North Maluku Communities Using Falah Approach. IKONOMIKA: Jurnal Ekonomi and Bisnis Islam, Volume 5, No 1, pp. 205 - 230

8. Dalamagas, Basil. 2010. Publik Sektor and Economic Growth: The Greek Experience. Bulletin of Indonesian Economic Studies. 32. Hal:277-288.

9. Diana Wrjayanti and Heri Wahono. 2005. Analisis Konsentrasi Kemiskinan di Indonesia Periode Tahun 1999-2003.Jurnal Ekonomi Pembangunan, Vol.10 No.3 Hal:215-225.

10. Kurniawati. 2017. Pengaruh Akuntabilitas Pengelolaan Keuangan Alokasi Dana Kampung, Kebijakan Kampung and Kelembagaan Kampung Terhadap Kesejahteraan Masyarakat (Studi Pada Kampung Distrik Sentani Kabupaten Jayapura). Jurnal Akuntansi \& Keuangan Daerah. 12 (2), Hal: 77-87.

11. Krisna Pratama, AA Gede and Ida Bagus Darsana. 2019. Pengaruh Kemiskinan and Investasi Terhadap Pertumbuhan Ekonomi and Kesejahteraan Masyarakat. Jurnal Ekonomi Pembangunan, Vol. 8 No. 6 Hal: 1300-1330.

12. Leker, L., \& Ponthiere, G. 2015. Education, Life Expectancy and Family Bargainning: The Ben-Porath Effect Revisited. Journal of Education Economic, 23(4), 481-513.

13. Mulyaningsih, Yani. 2008. Pengaruh Pengeluaran Pemerintah Di Sektor Pendidikan and Kesehatan Terhadap Pengentasan Kemiskinan Melalui Peningkatan Pembangunan Manusia di Provinsi Jawa Tengah. Jurnal Dinamika Ekonomi Pembangunan, Vol.1 No.1

14. Notoatmodjo, Soekidjo. 2009. Pengembangan Sumber Daya Manusia. Jakarta: Rineka Cipta.

15. Putra and Sri Budhi. 2015. Efektivitas and Dampak Program Nasional Pemberdayaan Masyarakat Mandiri Perdesaan (Pnpm-Mpd) Terhadap Peningkatan Kesejahteraan and 
Kesempatan Kerja Rumah Tangga Sasaran Di Kecamatan Abiansemal Kabupaten Badung. E-Jurnal Ekonomi and Bisnis Universitas Udayana, Hal: 183-196.

16. Sihite. (2020). Pengaruh Dana Desa, Ipm, and Pertumbuhan Ekonomi Terhadap Penurunan Tingkat Kemiskinan Di Provinsi Sumatera Utara. Universitas Sumatera Utara

17. Tajeddini Kayhan, Vanessa Ratten and Mela Denisa. 2017. Female Tourism Entrepreneurs In Bali, Indonesia. Journal of Hospitality and Tourism Management, Vol 31 Hal:52-58

18. Todaro, Michael P. 2000. Pembangunan Ekonomi Dunia Ketiga, Edisi Ketujuh (Alih Bahasa Oleh Drs. Haris Munandar, M. A). Jakarta: Erlangga.

19. 2003. Pembangunan Ekonomi Di Dunia Ketiga. (Alih Bahasa: Aminuddin and Drs.Mursid). Jakarta: Ghalia Indonesia.

20. Wardani and Utami. (2020). Pengaruh Transparansi Pengelolaan Keuangan Dana Desa and Pemberdayaan Masyarakat Terhadap Kesejahteraan Masyarakat Desa Sidoharjo. Jurnal Kajian Bisnis. 28 (1), Hal: 35-55.

21. Wiriana, I Gede; and I Nengah Kartika. 2020. Analisis Faktor-Faktor Yang Mempengaruhi Kesejahteraan Masyarakat Di Kabupaten/Kota Provinsi Bali Tahun 2012-2018. E-Jurnal Ekonomi Pembangunan Universitas Udayana, [S.I.], v. 9, n. 5, p. 1051 - 1081. ISSN 2303-0178. 